HOW

Volume 28, Number 2, pages 53 - 77

https://doi.org/10.19183/how.28.2.562

HOW

\title{
Pre-Service English Language Teachers' Levels of Reflectivity during the Process of Identity Construction in Pedagogical Practicum: A Snowball?
}

\author{
Niveles de reflexividad de los profesores de inglés en formación \\ durante el proceso de construcción de identidad en la práctica \\ pedagógica: ¿Una bola de nieve?
}

\author{
Angélica Pita-Castro ${ }^{1}$ \\ Alicia Castiblanco-Rincón ${ }^{2}$
}

\begin{abstract}
This research study is about the way pre-service English language teachers' levels of reflectivity, proposed by Van Manen, give an account of the construction of their identity as language teachers during their pedagogical practicum in a BA program of English Language Teaching at a private university in Bogota, Colombia. This study follows the principles of narrative research to explore the way the participants live their pedagogical practicum experience. Data were collected from the participants' reflective journals and audio-recorded semi-structured interviews. Findings reveal that pre-service English language teachers possess a level of reflectivity, although they are unaware of it at the beginning of their pedagogical practicum. Thus, their identities as language teachers are constructed depending on the context, the people that are around them, and the specific time; hence, the levels of reflectivity as proposed by Van Manen are set in an incognito manner.
\end{abstract}

She studied a BA Languages program at La Salle University in Bogotá, Colombia. She is in process to be certificate in an ELE program at Universidad Externado de Colombia. She is working in a homeschool program in a private school in Bogotá.

apita74@unisalle.edu.co

ORCID ID: https://orcid.org/0000-0001-9905-6263

She studied a BA Languages program at La Salle University in Bogotá, Colombia. She is working in a private school at Villavicencio, Meta.

ycastiblanco64@unisalle.edu.co

ORCID ID: https://orcid.org/0000-0003-3782-1905

Received: April 6th, 2020. Accepted: February 26th, 2021.

This article is licensed under a Creative Commons Attribution-Non-Commercial-No-Derivatives 4.0 International License. License Deed can be consulted at https://creativecommons.org/licenses/by-nc-nd/4.0 
Angélica Pita-Castro,

Alicia Castiblanco-Rincón

Keywords: identity construction, language education, levels of reflectivity, pedagogical practicum, pre-service teacher

\section{Resumen}

Esta investigación trata de la manera en que los niveles de reflexión, propuestos por Van Manen, de los profesores de inglés en formación dan cuenta de la construcción de su identidad como profesores de idiomas durante su práctica pedagógica en un Programa de Licenciatura en Enseñanza del Idioma Inglés en una universidad privada de Bogotá, Colombia. Este estudio sigue los principios de la investigación narrativa para explorar la forma en que los estudiantes viven su experiencia de la práctica pedagógica. Los datos se recopilaron utilizando los diarios reflexivos de los profesores de inglés en formación participantes y las entrevistas semiestructuradas grabadas en audio. Los hallazgos revelan que los profesores de inglés en formación tienen un nivel de reflexión, aunque lo desconocen al inicio de su práctica pedagógica. Así, sus identidades como profesores de idiomas se construyen en función del contexto, las personas que los rodean y el momento concreto; ambientando de forma incógnita los niveles de reflexión propuestos por Van Manen.

Palabras clave: construcción de identidad, educación en lenguaje, niveles de reflexividad, práctica pedagógica, profesor en formación.

\section{Introduction}

Throughout time, language teacher identity changes as it is constructed in the way education flows (Beijaard, 1995; Olsen, 2008). This identity is created and developed along the teaching process (Rodgers \& Scott, 2008). Nowadays, language teacher identity has received attention in the field of language education around the world. The process of constructing a language teacher identity entails many influences and factors such as social and historical contexts, emotions, beliefs, traditions, as well as job and life experiences, among many others (Beauchamp \& Thomas, 2011; Miller, 2009). With those influences, teachers usually create and (re-) construct their own identity, or identities, as a language teacher.

A good example in which those different influences take place is pedagogical practicum. For the context of BA programs of English language teaching, this space helps pre-service teachers to put theory and practice together (Castañeda-Trujillo \& Aguirre-Hernandez, 2018; Lucero \& Roncancio-Castellanos, 2019). Hence, it is in this space where pre-service

54 teachers find varied social problematics in teaching that they did not expect, and that have them reflect on what it is to be a teacher and what decisions to make in the classroom. As Castañeda-Peña, Rodriguez-Uribe, Salazar-Sierra, and Chala-Bejarano (2016) say, classroom management, confidence, and experience configure the decisions that pre-service teachers make for lesson delivery. Pedagogical practicum is then the most important moment for preservice teachers since this space greatly helps them construct their identity(ies) as language teachers. Emotions and reactions upon which they reflect from/on their teaching experiences during pedagogical practicum are a fundamental part in that identity construction. 
Likewise, reflection during pedagogical practicum gives pre-service teachers more information to analyze both what they do and are in the classroom, as well as how and why they do it (Castañeda-Trujillo, 2019; Lucero \& Roncancio-Castellanos, 2019). For instance, the more they pay attention to their students' needs, the more they can be able to think of and develop different activities for the students to learn in their own ways.

In addition, reflection helps pre-service teachers to think critically about the language teaching method and methodology that they use. As Kumaravadivelu (2008) affirms,

I consistently use a method to refer to established methods conceptualized and constructed by experts in the field (see text to come). I use the term, methodology, to refer to what practicing teachers do in the classroom to achieve their stated or unstated teaching objectives. (p. 84)

In our point of view, this affirmation means that pre-service teachers can follow a particular method, but when they apply it in a language class, it can change due to different factors (student attitude, environment, teacher's explanation, etc.). Eventually, the methodology (putting the method into action) changes to achieve teaching objectives. When this happens, pre-service teachers may start to reflect on the characteristics that they possess as language teachers. This delineates constant and valuable moments for the construction of their own identity as language teachers.

Identity is the sense that a person has of her/his self as an individual, including the person's self-awareness. Also, the notion of teacher identity highlights the individual characteristics of a teacher and how these are integrated with contextual possibilities and factors found in the content and methods of a specific field, as these are realized in specific contexts of teaching (Pennington \& Richards, 2016).

Within concrete contexts, teacher identity is constructed from social and personal perspectives (Jiménez-Castañeda, 2013; Olsen, 2008). According to Clark and Flores (2001), Miller (2009), Richards (2009), and Beauchamp and Thomas (2011), social perspectives involve the influences of the context, traditions, experiences, social interactions, culture, working context, curriculum, policies, teaching resources, and access to professional development. Meanwhile, personal perspectives include feelings, emotions, self-reflection, biography, and gender, among others.

All these personal and social factors are joined and cause changes in identity construction. Language teachers have the possibility to shape their identities in those changes. Therefore, social and personal interactions occupy an important place in helping teachers develop their identity as language teachers (Glotova \& Wilhelm, 2014; Lucero, 2020). Besides, the emotional part complements the teacher's identity. After all, teaching involves intellectual and emotional components. In many cases, the latter component, the emotional, is the most influential (Rodgers \& Scott, 2008). 
In this project, we concentrate on the personal perspective, working on the selfreflection proposed in Van Manen's theory (1977). In this theory, he explained three levels of reflectivity: technical rationality, practical action, and critical reflection. These three levels should be analyzed from/during past teaching events to improve the class in the future. We consider pedagogical practicum to influence the process to construct the identity of English language pre-service teachers as we know, "The development of a teacher identity is an intersection of different experiences and social interactions within the self, the family unit, the cultural community, and the schooling process" (Clark \& Flores, 2001, p. 70). We assume the construction of pre-service English language teachers' identity as a dynamic and complex process.

By considering the levels of reflectivity from Van Manen's perspective and the process of identity construction, the present study seeks to identify the pre-service English language teachers' levels of reflectivity during their pedagogical practicum in the BA program; then, to determine the manner in which their levels of reflectivity give an account of the construction of their identity as language teachers during this stage.

\section{Conceptual Framework}

\section{Levels of Reflectivity}

This concept refers to Van Manen's (1977) three levels of reflectivity: technical, practical, and critical. In Table 1 below, each level of reflectivity is defined. In unison, these three levels analyze past teaching events to improve a class in the future.

Table 1. Van Manen's Levels of Reflectivity

\begin{tabular}{|l|l|}
\hline \multicolumn{1}{|c|}{ Levels of Reflectivity } & \multicolumn{1}{c|}{ Definition } \\
\hline Technical Rationality (TR) & $\begin{array}{l}\text { - The teacher is concerned with the technical } \\
\text { application of knowledge and basic curriculum } \\
\text { principles (i.e., are the students on task?). }\end{array}$ \\
\hline Practical Action (PA) & $\begin{array}{l}\text { The teacher becomes more concerned with } \\
\text { clarifying assumptions while addressing educational } \\
\text { consequences (i.e., if and how are goals being met). }\end{array}$ \\
\hline Critical Reflection (CR) & $\begin{array}{l}\text { The teacher is concerned with the worth of } \\
\text { knowledge without a personal bias (i.e., how } \\
\text { was content important to students?). }\end{array}$ \\
\hline
\end{tabular}


Considering these three levels of reflection, a teacher needs to possess three characteristics for being reflective: open-mindedness, whole-heartedness, and responsibility (Dewey, 1933). Open-mindedness is the ability (1) to consider new problems and ideas free from prejudice and [possess] an active desire to listen to more sides than one, and (2) to recognize the possibility of error even in the beliefs that are dearest to the teacher. Responsibility is usually conceived as a moral trait rather than as an intellectual resource; nonetheless, it is an attitude that requires the teacher to win the adequate support of desire for new points of view and new ideas and of enthusiasm for and capacity for absorption in subject matter (Dewey, 1933, pp. 30-32).

In a study about pre-service teachers' levels of reflection, Castañeda-Trujillo and Aguirre-Hernández (2018) found the following:

The main conclusions indicated that pre-service teachers are engaged in constant reflection and make decisions on the spot based on their own personal vision of what can favor the educational situation, but this reflection just reached the technical level in most of the cases. (p. 158)

This premise helps one see that the level of reflectivity of pre-service teachers of English is the same in the first and last semester of practicum. By using Van Manen's (1977) three levels of reflectivity, we expect to see how the identity of the pre-service English language teachers is constructed from these three levels during their pedagogical practicum.

\section{Identity Construction}

In general, from a pedagogical perspective, teacher identity is understood as the distinctive features that a teacher has, or the personal or social meanings they ascribe to themselves (Beijaard, 1995; Olsen, 2008). Numerous studies (see for example the compilation in Bilgrami, 2001) have emphasized teacher identity in the social context of the educational environment. Rodgers and Scott (2008) also define teacher identity as being constructed, maintained, and negotiated primarily through discourse. In Lasky's (2005) point of view, teacher identity is the form in which teachers are defined and how others see them as teachers. Teacher identity is then a construction of the professional who evolves along her/ his educational career and who changes due to the influence of school, reforms, political contexts, personal commitment, and personal experiences according to time and place.

Pre-service teacher identity is influenced by the internal factor of emotions and the external factor of contexts (Rodgers \& Scott, 2008). The school climate, learners' characteristics, and interactions with colleagues and of school administrators can all be factors in shaping a pre-service teacher identity. Rodgers and Scott (2008) suggest that ideologies, discourses, and content play a role in teacher identity. In agreement with this, Franzak (2002) states the following: 
Angélica Pita-Castro,

Alicia Castiblanco-Rincón

We live in a world of negotiated identity, one where we continually construct and revise our vision of us. Those of us who create "teacher" as part of our identity must negotiate the particular implications of our professional identity in relation to students, peers, the general public, our intimates, and ourselves. (p. 258)

Identity cannot be classified or said to be the same as another. It is an amalgam of the incorporation of factors from social and personal perspectives. As Morgan (2004) says, "a line of research closely analyzes the concept of identity, not as a set of defined and coherent features, but as something complex, often contradictory and subject to changes throughout the time and place" (p. 112).

From Norton's (2006) perspective, the experiences of a teacher, either novice or experienced, as to gender, race, class, culture or sexual orientation, are shaped by the processes of instruction and interaction that evolve within specific sites of bilingual education and second or foreign language. These influencing factors make their process of identity construction a reflective one according to each of the experienced situations in which each one has been confronted. Thus, identity construction is reflected more in the external than in the personal. From this perspective, both professional and personal identity are regulated and attributed with all forms of human activity: oral and written texts, gestures, images and spaces, development within the institutions, academic disciplines, and broader social formations. Hence, teachers' social contexts influence their identity construction.

\section{Pedagogical Practicum}

In Colombia, the National Ministry of Education (MEN, 2016) understands pedagogical practicum as:

A process of self-reflection, which becomes the space for conceptualization, research and didactic experimentation, where the undergraduate student approaches knowledge in an articulated manner and from different disciplines that enrich the understanding of the educational process and the teaching function in it. This space develops in the undergraduate student the possibility of reflecting critically on his practice from the registration, analysis and continuous balance of its pedagogical actions, consequently, the practice promotes the development of the professional competencies of the future graduates. (p. 5)

Also, Richards and Crookes (1988) explain pedagogical practicum as:

Practice teaching, also practicum, teaching practice opportunities provided for a student teacher to gain teaching experience, usually through working with an experienced teacher - the CO-OPERATING TEACHER - for a period by teaching that teacher's class. Practice teaching experiences may include MICRO TEACHING, teaching an individual lesson from time to time, or regular teaching over a whole term or longer, during which the student teacher has direct and individual control over a class. Practice teaching is intended to give student teachers experience of [in] 
classroom teaching, an opportunity to apply the information and skills they have studied in their teacher education programme, and a chance to acquire basic teaching skills. (p. 14)

In agreement with Castañeda-Trujillo (2019), Lucero and Roncancio-Castellanos (2019), and Ubaque-Casallas and Aguirre-Garzón (2020), pedagogical practicum is the opportunity for pre-service teachers to improve upon what they have learned during the semesters of theory, as well as being a space that can help pre-service teachers to analyze their teaching skills, put into practice techniques, and reflect if these instruments work or not in the classroom. As Fandiño Parra and Bermúdez Jiménez (2015) say,

Por un lado, es una noción metodológica sobre aquello que acontece en el salón de clase y de lo que bace cotidianamente el profesor. Por otro, es una noción discursiva, constituida por el triángulo escuela-docente-saber pedagógico. De esta manera, la PP da cuenta tanto de las prácticas como de los discursos que circulan en las aulas con el objetivo de discernir las formas de enunciación y de legitimación de los saberes enseñados en las instituciones. ${ }^{3}$ (p. 32)

This quote provides an explanation of what pedagogical practicum likely is for BA programs of English language teaching in Colombia. We can say that pedagogical practicum in the context of the current research study refers to all the things that can occur in the classroom, all the factors that take place during a class session (the activities, the students' and pre-service English language teacher attitudes, etc.). Also, the pedagogical practicum is the space for pre-service English language teachers to reflect on what they have done during their classes to improve the future sessions; they need to become aware of their own process of practicum (Samacá-Bohorquez, 2012).

\section{Pre-Service Teachers}

According to Richards and Schmidt (2002), pre-service teachers are "Those students who participated in pre-service training or education, a course or program of study which student teachers complete before they begin teaching" (p. 416). Also, Bransford, DarlingHammond, and LePage, (as cited in Mergler \& Spooner-Lane, 2012, p. 66) and GonzálezMoncada (2003) explain that the goal of pre-service teacher education programs is to prepare students to become quality teachers equipped with pedagogical practices. These teacherstudents will work in educational institutions to meet the increasing demands associated with the teaching profession. The above means that a pre-service teacher needs to be open to new pedagogical practices to solve problems in the educational field. Pre-service teachers need to increase the quality of education, "to raise the quality of teaching in order to increase the

On the one hand, it is a methodological notion about what happens in the classroom and what teachers do every day. On the other hand, it is a discursive notion, constituted by the school-teacher-pedagogical knowledge triangle. In this way, the PP gives an account of both the practices and the discourses circulating in the classrooms with the aim of discerning the forms of enunciation and legitimation of the knowledge taught in the institutions. (Fandiño Parra \& Bermúdez Jiménez, 2015) 
Angélica Pita-Castro,

Alicia Castiblanco-Rincón

effectiveness of schooling and to improve student outcomes," as Mergler and Spooner-Lane (2012, p. 66) state.

\section{Research Design}

The type of research of this study is a qualitative narrative inquiry under a descriptive analytical perspective. Quintero-Mejía (2018) talks about narrative as a data collection strategy, namely: "En la medida en que las historias narradas han sido vividas, hacen parte de la reflexión acerca de la vida bumana y se ponen a disposición de otras y nuevas reinterpretaciones de quienes escuchan o leen" ${ }^{4}(\mathrm{p}$. 120). McMillan (2016) explains that the goal of narrative inquiry "is to use individuals' actual lived stories to provide a deep and rich understanding of a specific phenomenon, often best communicated as a story that can be compelling. Narrative research is used to establish and study meaningful stories" (p. 321). This author also presents types of narrative designs i.e., "oral and life history, auto ethnography, bibliographical, and psychological" (p. 321). Concerning these types of narratives, we highlight the following that are closely connected to our study:

- Continuity of experience, in which stories are organized and communicated temporally, in a logical and meaningful sequence and chronology.

- Use of several sources of data, including participant stories, such as observation, documents, work samples, and others' viewpoints.

- An emphasis on context and situation, noting how stories are related to social culture; narratives occur in specific places and situations.

- Exploration of identity formation, in which participants define themselves.

- An emphasis on "turning points", critical moments that elucidate meanings.

- The collaborative relationship between the researcher and participant(s), in which stories are co-constructed.

These characteristics are articulated to our research project in the use of restoring, or the "told story" that takes the words of pre-service English language teachers and rewords these texts in the words of the researcher. Serrat (2008) states that storytelling is a way to see how the levels of reflection work on pre-service English language teachers i.e., "Storytelling is the vivid description of ideas, beliefs, personal experiences, and life -lessons through stories or narratives that evoke powerful emotions and insights" (p. 322). To put it in another way, storytelling is the use of stories or narratives as a communication tool.

To the extent that the narrated stories have been lived, these are part of the reflection on human life; the stories are then available to others, and new reinterpretations of those who listen to or read them can emerge. (Quintero-Mejía 2018) 


\section{Context and Population}

The participants are composed of four pre-service English language teachers ${ }^{5}$ that began their first semester of pedagogical practicum in 2018 and finished this stage in 2019 after three semesters of practicum. These three semesters of pedagogical practicum cover the last two years of their major in English language teaching. Their first practicum was at a public school from January to May 2018; their last practicum took place at a different public school from February to May 2019. One of the participants did her last practicum in a private university. The participants' original names were replaced by pseudonyms.

\section{Instruments}

Two instruments were used to collect the told stories of the participants: reflective journals and semi-structured interviews. The told stories, as McMillan (2016) indicates, "Emanate directly from the participant, through both formal and informal conversation" (p. 321). Restoring allowed us, as researchers, to develop a sequence of events reported by the participants in the abovementioned techniques while establishing cause and effect in a chronological line. This form of data collection was for rewriting the experiences that the participants underwent in their first and last pedagogical practicum.

\section{Pre-service English Language Teachers' Reflective Journals}

This instrument exposes, as Lavov explains (as cited in Quintero-Mejía, 2018, p. 35), the experiences about situations that the participants lived during their pedagogical practicum in a natural way. The journals served to analyze the processes of reflection that the participants achieved in their first semester of pedagogical practicum. The journals were written by the participants as part of the practicum portfolio. They contained around eight to ten entries, 100-150 words each, in which each participant wrote about (1) what they had lived during the class delivery, (2) the aspects that they considered caused difficulties, or (3) the aspects that made them comfortable.

\section{Semi-Structured Interviews}

We applied them in line with McMillan's (2016) suggestions. We audio-recorded and collected details and experiences of pedagogical practicum directly from the participants. We asked them questions selected in advance about the experiences and reflections written

These participants were selected from a pedagogical practicum group that worked on the process of reflection on their teaching experiences through journals. Out of the pre-service teachers of this group, these four participants presented dissimilar teaching experiences and attitudes in their journals. These experiences and attitudes are presented in the section of disclosure below. 
Angélica Pita-Castro,

Alicia Castiblanco-Rincón

in their journal entries; furthermore, we decided the sequence and wording of the questions during the interview with pre-established prompts and probes. With those interviews, we obtained information relevant to determine the construction of the participants' identity as language teachers during their pedagogical practicum.

\section{Data Analysis}

We analyzed the instruments by applying matrices of narratives ${ }^{6}$. Quintero-Mejia (2018) says that a narrative helps identify and comprehend situations in a culture or social structure. Accordingly, we compiled aspects that expose the time or period, the experience, the events, feelings and emotions, and the people that participated in the events. We did a matrix of narratives for each instrument and participant. The first matrix was filled with information taken from the journals; we read the four journals and after that we completed the matrix considering the abovementioned categories. The second matrix was completed with information taken from the semi-structured interview complementing or extending the aspects of the mentioned categories.

At the end of the process, we did analyze three different explanatory textual units. The first one compiled the common aspects mentioned by the participants in their journals, and the second, the complementary information collected in the semi-structured interviews. The third textual unit unified the analysis of the two matrixes of narratives and the two previous units. This final text exhibited all the aspects together and the participants' personal preferences and opinions about their period of practicum.

\section{Disclosure}

This section is presented in a unique narrative text, combining both Spanish and English. This combination uses direct quotes and citations, which were in both languages, of the participating pre-service English language teachers. Considering that at the moment of listening to and seeing the information in the data collection instruments, the pre-service English language teachers had included much richness when they created their discourse in Spanish, in spite of the fact that they usually used English in academic activities.

Moreover, as Quintero Mejia (2018) says:

El valor ético de la narrativa se ilustra con el género trágico porque se considera que su estructura narrativa revela los vicios y las crueldades humanas que ponen en juego la libertad... Con los griegos aprendimos que

The matrices are in the appendixes at the end of the article. 
en las narrativas encontramos tanto nuestra naturaleza necesitada como nuestra condición de seres frágiles.7 (p. 116)

Parallel to this, we know that the narrative in the original language is related to other links that establish a relationship between an individual and others. Besides, Quintero Mejia (2018) affirms: "Una vida sin narrar se reduce a ser un fenómeno biológico, pues careceríamos de interpretación y de reflexión acerca del devenir de la vida y de la cultura" ${ }^{8}$ (p. 85).

We metaphorically associate the narrative of the findings to a snowball. The snowball metaphor is used to explain that by taking advantage of every opportunity to improve skills, greater performance can be achieved, leading to optimal development. We saw that the participants' identity evolved throughout the semesters of pedagogical practicum as a snowball that will continue evolving and helping them to improve their teaching skills.

\section{Starting the Pedagogical Practicum}

To start our findings, we want to talk about their first semester of pedagogical practicum. The pre-service English language teachers confronted face to face their identity as language teachers, the same identity that at some point they thought they had defined and which had become unquestionable. Figure 1 below represents the way the pre-service English language teachers see themselves in their first pedagogical practicum. Their level of reflectivity is technical.

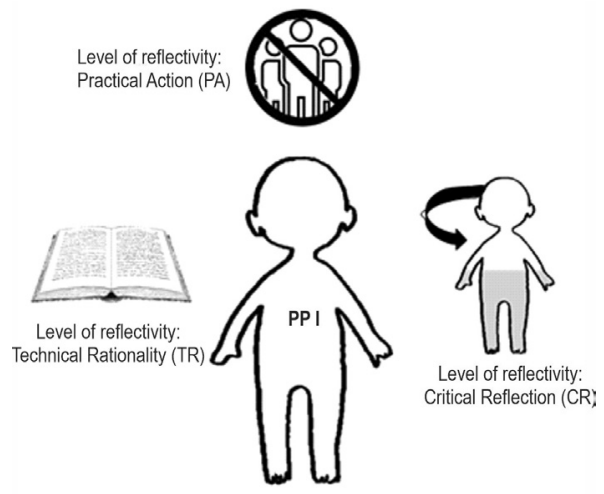

Figure 1. First Pedagogical Practicum

The ethical value of the narrative is illustrated by the tragic genre because its narrative structure is considered to reveal the human vices and cruelties that put freedom at stake... With the Greeks we learned that in narratives we find both our needy nature and our condition as fragile beings. (Quintero Mejia, 2018)

8 A life without narration is reduced to being a biological phenomenon, because we would lack interpretation and reflection about the future of life and culture. (Quintero Mejia, 2018) 
Angélica Pita-Castro,

Alicia Castiblanco-Rincón

The ways of seeing themselves, as Figure 1 represents, goes in line with Van Manen's (1977) technical rationality in his theory of reflectivity. He states that the first level refers to what teachers are supposed to achieve in their classes, to the technical application of educational knowledge and basic curriculum principles in order to achieve a certain end. Regarding this level, Van Manen (1977) explains, "the practical is concerned mainly with means rather than ends" (p. 226). It means that, as Kay (2006) said, "the teacher is concerned with technical application of knowledge and basic curriculum principles (i.e., are the students really on-task?)" (p. 29). Considering this, the four pre-service English language teachers in their first pedagogical practicum reached this level, but in an unconscious way, because there were not enough spaces for self-reflection.

However, those cases in which the pre-service English language teachers were exposed to this type of situations popped up noticeably: "I thought many new words and as the topic of this period are the colors, I decided to use cold and warm colors" [sic], "in this activity, I worked on the topic 'ALL ABOUT ME' so that they could write their likes about movies, colors, and subject and draw their family" [sic] (Valeria wrote in her first class, 2017).

Practical action in Van Manen's (1977) theory refers to "the technical application of educational knowledge and basic curriculum principles pursuing to attain a given end" ( $p$. 226). Following this idea, Kay (2006) explains that practical action is when a "Teacher becomes more concerned with clarifying assumptions while addressing educational consequences (i.e., if and how are goals being met)" (p. 29). Considering all this, the four participating preservice English language teachers could give an account of this level in their journal entries during their first pedagogical practicum; although in some cases, this level worked in the wrong way: "We were continues [sic] with our activity about the body but this activity is a song, she had to dance and sing," "The song, in the first time played the song, they tried to dance, to imitate the dancer, for the first was ok," [sic] "In the others, when I played the song, they danced and sang, but when the song finished, she began to run around the classroom," "She began to run around the classroom and started screaming," "Everything was out of control" [sic] (Julieth expressed in her journal, 2018).

The last Van Manen's (1977) level is critical reflection, considered as "the process of analyzing and clarifying individual and cultural experiences, meanings, perceptions, 64 assumptions, prejudgments, and presuppositions, for the purpose of orienting practical actions" (p. 226). On this matter, Van Manen (1977) says: "It is assumed that every educational choice is based on a value commitment to some interpretive framework by those involved in the curriculum process" (p. 226). Kay (2006) corroborates that critical reflection is when a "Teacher is concerned with worth of knowledge without a personal bias (i.e., was content important to students?)" (p. 29). In the first pedagogical practicum that the four preservice English language teachers completed, this level of reflectivity was rather absent, only found at the end of their three semesters of practicum. For example, this was taken from 
their journal entries: "Finally on this day, I understood the difficult role of being a teacher," "I understood how my school's professors felt when teaching in a restless and distracted [form]" [sic] (Valeria said in her journal in 2018).

Considering this first experience, the four pre-service English language teachers felt something different: "In the first observation, I was nervous, I was afraid because it was my first time in the classroom" [sic] (Julieth wrote in her journal in 2018), "Al entrar al salón un grupo de cariñosas niñas me recibieron haciéndome preguntas que paso a paso fui respondiendo," "El control que generó la profesora, me llamó la atención, pues con mucha calma controlaba la hiperactividad de las niñas." "(Valeria wrote in her journal in 2018). Nevertheless, for them, the homeroom teacher's ideal was to keep a classroom organized, so the students did that accordingly. In most of the cases, the four pre-service English language teachers analyzed the attitudes and behaviors that came from their peers, and used the details that would help them, "I think that we as teachers must understand that kids always want to do something and is going to be really difficult to make them stay quiet and sit two hours, that's really boring" [sic] (María said about her session in 2018), "Analizaba desde el puesto en el cual decidí sentarme ya que tenía buena visibilidad del salón" 10 (Valeria wrote in her journal in 2018).

These situations were like a test because of their context. In this case, a classroom full of little heads was not always the expected one in order to apply a certain activity that took a suitable amount of time for its preparation: "Today was a difficult day, the girls did not want to work, other gave the work without following the instruction," [sic] "They were very restless, which made our activity difficult," "Not many felt encouraged to do the task, even those who gave the best activities did not want to try to deliver a good job" [sic] (Valeria wrote in her journal in 2018).

Despite being immersed in those kinds of situations, "It was very frustrating because they did not know what we were saying, something that did not happen before" Jhonatan wrote in his journal in 2018]), the four pre-service English language teachers found a balance that gave them a short break from the pressure that they had experienced about being the best teacher or the most loved teacher in the institution, and the best pre-service teacher in their practicum group. This is a way the participants construct(ed) a distinctive feature about themselves: "Although not everything was bad, because as always the wise girls delivered a nice job and were very active asking for the words that appeared in the alphabet soup," "We

\footnotetext{
"As I entered the classroom, a group of loving girls welcomed me by asking me questions that I responded to step by step." "The control generated by the teacher caught my attention, as she calmly controlled the hyperactivity of the girls." (Valeria's Journal, 2018)

10 "I was analyzing the situation from the place where I decided to sit down as I had good visibility of the room.” (Valeria’s Journal 2018)
} 
Angélica Pita-Castro,

Alicia Castiblanco-Rincón

know, not every day is good, and even they wake up without encouragement to do their work" (María reported in her journal in 2018).

At the end of this first experience, although not all of the four pre-service English language teachers did a reflection of themselves from their own critical perspective, they certainly found details that could be better: "I realized that I didn't consider speed which I was teaching, I was really slowly and some of the students started to feel bored," "That was one of the first things that I realized and learn that no everyone works at the same speed and that we as teachers must have a balance between fast and slow to make the lesson work." [sic]

These previous quotes reveal the way Maria constructs a distinctive feature about herself. These details astonished their lives; the four pre-service English language teachers saw and listened to their students, despite the experience of when they had also been students: "I felt really bad because I felt again that I had wasted my time and that they were not learning" (Jhonatan wrote in his journal in 2018). The four pre-service English language teachers found their interests: "In conclusion, I felt good because I love the children, I wanted this I want to teach to children," [sic] "I prefer preschool, kinder garden, but it's ok," "They are so cute" (Julieth wrote in her journal in 2018).

\section{Finishing the Pedagogical Practicum}

In the last semester of pedagogical practicum, the level of technical rationality that the four pre-service English language teachers showed was evident only in response to a semistructured interview. Figure 2 below represents the way the pre-service English language teachers saw themselves in their last pedagogical practicum. Their level of reflectivity is practical but not technical; the critical level is present although they are unaware of it due to a lack of teacher's assistance.

Also, in this case, as Figure 2 shows, the technical level exists, but the four pre-service English language teachers are not aware of their reflectivity. As Van Manen (1977) explains, this level is about the curriculum and the basic application of the curriculum. In this case, the four pre-service English language teachers did not propose or look for different ways to apply the curriculum or to improve the curriculum in future classes. These situations were remarkable because they tried to go beyond and tried new things: "Hice una especie de workshop, les llevé pues una lectura, entonces digamos yo les leí toda la lectura, les iba traduciendo, les iba diciendo jay esto es tal, esto es tal! la lectura es sobre esto..." "(Jhonatan said in his interview)

Furthermore, practical action level in the last semester of pedagogical practicum was visible in the same interviews. This occurred in the cases when the four pre-service English

11 "I did a kind of workshop, so I gave them a text, so let's say I read all the text with them, I was translating it to them, I was telling them, oh this is it, and this is it! The reading is about this..." (Jhonathan's interview) 
Pre-Service English Language 'Teachers' Levels of Reflectivity during the Process of Identity Construction in Pedagogical Practicum: A Snowball?

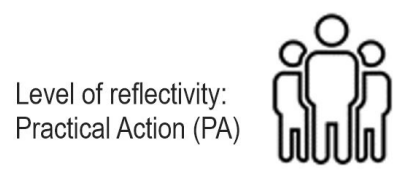

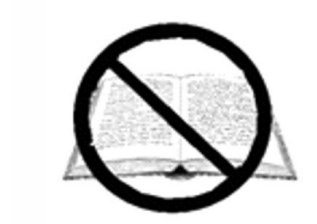

Level of reflectivity: Technical Rationality (TR)
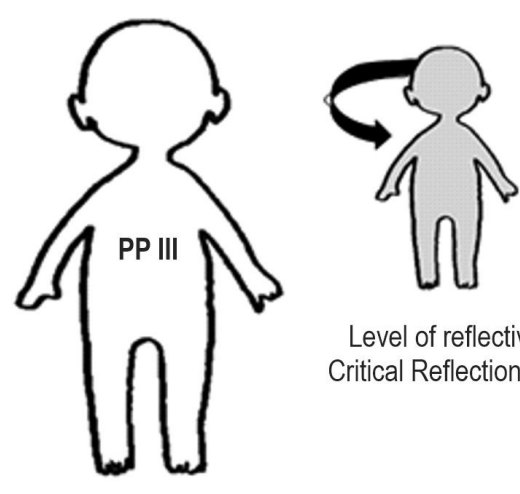

Level of reflectivity: Critical Reflection (CR)

Figure 2. Last Pedagogical Practicum

language teachers were aware of their actions to achieve certain goals that they had proposed for their classes. As Kay (2006) affirms, "Teacher becomes more concerned with clarifying assumptions while addressing educational consequences" (p. 29).

Valeria said in her interview that,

Vimos una película, los puse a ver una película y como son A1, pues no puedo ponerles así como Terminator, ni nada de esas cosas, entonces tocó ponerles la de la niña ésta de los ojos de botón..." "Pues es acorde al nivel, yo no les puedo poner nada así con unos diálogos ni los bijuemadres, porque no les puedo poner subtitulos." "Los puse a ver la película y no, super distraidos, yo les habia dicho que trajeran comida, empezaron a tirar el maí pira, fue un desastre horrible..." "Eso lo espero de un niño, ni siquiera los niños con los que trabajé en la otra práctica," "Ellas eran super organizadas, ellas ni comian en el salón para no ensuciar los puestos de las otras chicas..." 12 [sic]

12 "We saw a movie, I have them see a movie and since they are A1, I can't give them Terminator or any of those things, then I had to give them that of the girl's button-eyed..." "Because it's according to the level, I can't put anything like that with some dammed great [Hijuemadre: expression used to refer to something complicated or difficult according to the context] dialogues, because I can't set subtitles." "I have them watch the movie and they got super distracted. I had told them to bring food, they started throwing the popcorn, it was a horrible disaster..." "I expect that from a boy, not even the children I worked with at the other practicum," "They were super organized, and they didn't even eat in the classroom not to dirty the other girls' places..." [sic] (Valeria's interview) 
Angélica Pita-Castro,

Alicia Castiblanco-Rincón

This level, practical action, was presented in the interviews with the four pre-service English language teachers. Nevertheless, critical reflection, the last level of reflectivity, was difficult to differentiate in the interviews from the practical action level. The boundaries where one finishes and the other starts are blurred.

The last level of reflectivity in Van Manen's (1977) theory is critical reflection. It is supposed to be the main goal for teachers to improve their future classes. Nevertheless, it was the most complicated level since the pre-service English language teachers were not aware of their process of reflectivity (another way of constructing a distinctive feature about themselves). In this level, the four pre-service English language teachers could reflect on the moments that they lived with their students, as Julieth expressed to her interviewer, “... uno también aprende a cómo comportarse, a como ellos se comportan," "una vez. llegó una estudiante que la estaban cascando," "yo le dije: no, no le pegues," "tú no tienes por qué pegarle." "Abí es cuando uno se da cuenta que uno debería ver psicología en nuestra carrera." 13

Moreover, the last semester of pedagogical practicum could promote learning experiences for the four pre-service English language teachers. They had already lived different environments, a lot of individual experiences; however, some of them had similar opinions as in the first practicum. "Digamos que uno que nunca ba trabajado, esa práctica no le sirve para nada" ${ }^{14}$ (Jhonatan reported in his journal, 2019).

In these instances, the four pre-service English language teachers had already lived different kinds of experiences, and now, they were available to understand the why of those school moments. This shows how the participants constructed more distinctive features about themselves: "... Como me toca con los chinos* antes del descanso no están tan alborotados, "sin embargo, esos detalles pasan una mala jugada. Parce hay veces que lo enloquecen a uno," "La ver.pasada intenté un jueguito y jum parce*, les puse el juego, y esos chinos se alborotaron," "me tenían enloquecido, yo era ya que se acabe esta clase" ${ }^{15}$ (Jonathan said in the interview, 2019).

Additionally, the four pre-service English language teachers worked with students just as those but these students studied different things. Nevertheless, they, as teachers, were uncomfortable, because, "Lo único que no me gusta es cuando llegan a calificarme, me interrumpen la clase, entonces si yo les estoy explicando un tema (Estudiantes), dicen como "Yo creo que la mejor forma

13 "We also learn how to behave, also to see how they behave," "Once a student arrived, one that someone was hitting her," "I told him: No, don't hit her," "You don't have to hit her." "That's when you notice that you should see psychology in your major." (Julieth's interview)

14 "Let's just say that one, who has never worked, that practice doesn't work at all." (Jhonathan's journal)

15 "As I am with the children*(Chinos: expression used to refer to children without orientation to a specific nationality) before the break they are not so rowdy," "however, those details give us a bad moment. There are times when you go crazy," "Last time I tried to play a little game and jump parce*(expression used to refer to a friend or partner), I put the game on them, and those children* rioted," "I was freaking out, I was just about to finish this lesson.” (Jhonathan's interview) 
Pre-Service English Language Teachers' Levels of Reflectivity during the Process of Identity Construction in Pedagogical Practicum: A Snowball?

es esta y entonces puedes interactuar con los estudiantes," "Lo que hace que ellos sientan que yo soy otro estudiante más y que no tengo pues esa autoridad de profesora" ${ }^{16}$ (Valeria said in the interview, 2019).

On the other hand, the four pre-service English language teachers gave an account of their different characteristics that they never were supposed to have (characteristics that construct more distinctive features about themselves): "O sea yo no soy de los profes de los que empiezan a gritar para que se calmen, yo prefiero que se enloquezcan," "O sea no prefiero que se enloquezca, pero me da una pereza tener que gritarlos." ${ }^{17}$ In addition, note their preferences for giving lessons as well: "El semestre pasado que yo estuve aqui tampoco me gustó, porque no me gusta con grandes lo mío son los niños chiquitos." "Yo siempre he querido, estudiar, trabajar con niños porque amo los niños" 18 (Julieth said in the interview, 2019).

In the same way, "Pues aprender como tal el rol del profesor, sí, uno se da cuenta que les toca a ellos es muy duro," "Ese tema de las planeaciones, que no se encuentren los unos con los otros, porque uno tiene muchas ideas para la clase, uno tiene muchas actividades que hacer y todo, pero resulta que esa actividad se combina con un tema que vas a ver o ya viste" ${ }^{19}$ (Julieth said in the interview, 2019).

In shorter words, "... una práctica en colegio como que sí lo pone a uno en la realidad de lo que es," "Porque en él [colegio público que me tocó], las clases nunca me funcionaron tanto y pues en éste lado también me han funcionado," "Porque abi si le toca uno... (Sonido de palmada) uno se estrella cuando se le descontrolan a uno, uno es como, marica, ¿qué voy hacer?" ${ }^{20}$ (Jhonatan said in the interview).

Even so, other pre-service English language teachers might have a different perspective about it: "Igual no quiero ser profesora," "Es que no me gusta," "me gusta más la traducción." 21 But

16 "The only thing I don't like is when they get to grade me, they interrupt my class, so if I'm explaining a subject to them (students), they say like "I think the best way is this and then you can interact with the students," "Which makes them feel that I'm just another student and that I don't have that teaching authority." (Valeria's interview)

17 "I mean, I'm not one of the teachers who starts yelling for them to calm down, I'd rather let them go crazy," "I mean, I don't want them to freak out, but I'm lazy to have to yell at them." (Julieth's interview)

18 "Last semester when I was here, I didn't like it either, because I don't like it when I have big kids, mine are the little kids" "I've always wanted to study, work with children because I love children." (Julieth's interview)

19 "For learning the role of the teacher, yes, one realizes that it is up to them, it is very hard," "That subject of planning, that you don't meet each other, because you have a lot of ideas for the class, you have a lot of activities to do and everything, but it turns out that the activity is combined with a subject that you're going to see or you saw." (Julieth's interview)

20 "A school practicum like that does put you in the reality of what you are," "Because in it [public school where I was], the classes never worked such well for me and on this side they have also worked for me," "Because there you have to... (Applause) we crash when we get out of control, we are like, marica* (although a vulgarity, this word is used to refer to a friend or partner in a friendly way), what am I going to do?" (Jhonathan's interview)

21 "I don't want to be a teacher anyway," "I just don't like it," “I like the translation better." (Valeria's interview) 
Angélica Pita-Castro,

Alicia Castiblanco-Rincón

furthermore, they did not forget it in their future. "Mientras consigo para la especialización, trabajo como profesora, pero en un jardín de niños" 22 (Valeria said in the interview, 2019).

\section{When the Snowball Clashes: As a Matter of Discussion}

In their first pedagogical practicum, the four pre-service English language teachers accomplished the level of technical rationality; however, this level happened in an unconscious way because there were no spaces for self-reflection in their teaching context and pedagogical practicum tutorials. This is one of our most important findings since we noticed that the levels of reflexivity are reflected in their journals although the participants were not aware of these levels because they did not have spaces for self-reflection. Following this idea, the question is, why did the four pre-service English language teachers not have spaces for self-reflection? Does it happen in all the spaces of pedagogical practicum in the BA programs? If there are spaces for self-reflection, how do they occur?

About the beginning of the pedagogical practicum, the level of critical reflectivity was not much found; it occurred only at the end of the pedagogical practicum. As one preservice teacher said, "Finally, on this day, I understood what difficult role of being a teacher" [sic]. So, the question is, why do pre-service English language teachers seem to achieve a kind of critical level at the end of the practicum when (levels of) reflection should be present in each academic space, according to the BA curriculum?

At the end of pedagogical practicum, we could notice that the four pre-service English language teachers said something like "yo aqui tampoco aprendí nada," ${ }^{23}$ although they were aware of the type of students that they would prefer "yo siempre he querido estudiar, trabajar con niños porque amo los niños," and "No, a mi me gustan más los niños, es más fácil para trabajar la creatividad con ellos." ${ }^{24}$ These quotations show how the four pre-service English language teachers were starting to be critical about their process and about their teaching preferences. The question here is, why do pre-service English language teachers achieve awareness about their preferences in teaching only when they are in their last pedagogical

70 practicum? Is it because of the experience gained? Is it because they have constructed a different set of identities that can better fit into a variety of scenarios, with different kinds of people?

\footnotetext{
22 "While I get for a specialized course, I work as a teacher, but in a kindergarten." (Valeria's interview)

23 "I didn't learn anything here either."

24 "I have always wanted to study and work with children because I love children," and "No, I like children better, it's easier to work on creativity with them."
} 


\section{Conclusion}

We can say that the participating pre-service English language teachers' level of reflectivity was mostly technical, at the start of pedagogical practicum that is, and a bit practical and critical at the end of this stage. It seems to be that they were not much aware of these levels because (1) they did not feel the teacher's assistance in this stage; (2) they did not have spaces for reflection after each pedagogical practicum; or (3) of their lack of interest in personal reflection.

The pre-service English language teachers showed an important aspect about how they construct their identities as language teachers: The identities cannot be classified. That means that each displayed identity of our participants is different and unique in their own context. We then want to clarify that determining the relationship that occurs between identities and levels of reflectivity depends on the environment that each pre-service English language teacher is living and the people around them. The multiplicity of all those identities does not allow a classification of them and a further connection to any level of reflectivity unless the context where they occur and the level of reflectivity that each pre-service English language teacher has are deeply explored. What is also evident is that, in most of the cases, the preservice English language teachers were not very much aware of their multiple identities since these were varied and multifaceted. We observed that the identities that they may have constructed during the semesters of theory tend to be shown in the practicum. Thus, during the semesters of theory, the language teacher identities seem to be in the dark; as such, during the pedagogical practicum stage, those identities eventually pop up as their teaching experiences start to grow.

\section{References}

Beauchamp, C., \& Thomas, L. (2011). New teachers' identity shifts at the boundary of teacher education and initial practice. International Journal of Educational Research, 5, 6-13.

Beijaard, D. (1995). Teachers' prior experiences and actual perceptions of professional identity. Teachers and Teaching, 1(2), 281-294.

Bilgrami, A. (2001). Identity and identification: Philosophical aspects. In N. J. Smelser, \& P. B. Baltes (Eds.), International encyclopedia of the social \& behavioural sciences (pp. 7149-7154). Elsevier.

Castañeda-Peña, H., Rodríguez-Uribe, M., Salazar-Sierra, A., \& Chala-Bejarano, P. A. (2016). Narrative events of pre-service teachers at the end of their teaching practicum with regard to their pedagogical advisor: Learnings reported. Signo y Pensamiento, 35(68), 52-64.

Castañeda-Trujillo, J. E. (2019). (Re)clamando por un cambio en el concepto de formación inicial de profesores. Enletawa Journal, 12(1), 62-79.

Castañeda-Trujillo, J. E., \& Aguirre-Hernández, A. J. (2018). Pre-Service English teachers' voices about the teaching practicum. HOW, 25(1), 156-173. https://doi.org/10.19183/how.25.1.420 
Angélica Pita-Castro,

Alicia Castiblanco-Rincón

Clark, E. R., \& Flores, B. B. (2001). Who am I? The social construction of ethnic identity and self-perceptions in Latino preservice teachers. Urban Review, 33, 69-86. https://doi. org/10.1023/A:1010380206373

Dewey, J. (1933). How we think: A restatement of the relation of reflective thinking to the educative process. Houghton Mifflin Company.

Fandiño Parra, Y., \& Bermúdez Jiménez, J. (2015). Práctica pedagógica: Subjetivar, problematizar y transformar el quehacer docente. In R. M. Páez Martínez (Ed.), Práctica y experiencia: Claves del saber pedagógico docente (pp. 29-54). Ediciones Unisalle.

Franzak, J. (2002). Developing a teacher identity: the impact of critical friends' practice on the student teacher. English Education, 34(4), 258-280.

Glotova, D., \& Wilhelm, A. (2014). Teacher's self-concept and self-esteem in pedagogical communication. Social and Behavioral Sciences 132, 509-514.

González-Moncada, A. (2003). Who is educating EFL teachers: A qualitative study of in-service teaching in Colombia. Íkala, Revista de Lenguaje y Cultura, 8(14), 153-172.

Jiménez Castañeda, O. D. (2013). La construcción de la identidad de los maestros de Básica secundaria, un estudio de caso [Unpublished doctoral dissertation], Universidad Nacional de Colombia.

Kay, K. (2006). Using Van Manen's model to assess levels of reflectivity among preservice physical education teachers [Unpublished doctoral dissertation]. Tarleton State University.

Kumaravadivelu, B. (2008). Understanding language teaching from method to post method. Taylor \& Francis e-Library.

Lasky, S. (2005). A Sociocultural approach to understanding teacher identity, agency and professional vulnerability in the context of secondary school reform. Teaching and Teacher Education, 21, 899-916.

Lucero, E., \& Roncancio-Castellanos, K. (2019). The pedagogical practicum journey towards becoming an English language teacher. Profile: Issues in Teachers' Professional Development, 21(1), 173-185. https://doi.org/10.15446/profile.v21n1.71300

Lucero, E. (2020). Bringing interactional identities into the study of classroom interaction in ELT education. GiST, Education and Learning Research Journal 20(1), 135-153. https://doi. org/10.26817/16925777.714

McMillan, J. (2016). Fundamentals of educational research ( $7^{\text {th }}$ ed.). Pearson.

Mergler, A. G., \& Spooner-Lane, R. (2012). What pre-service teachers need to know to be effective at values-based education. Australian Journal of Teacher Education, 37(8), 66-81.

Miller, J. (2009). Teacher identity. In A. Burns \& J. C. Richards (Eds.), The Cambridge guide to second language teacher education (pp. 172-183). Cambridge University Press.

Morgan, B. (2004). Teacher identity as pedagogy: Towards a field-internal conceptualisation in bilingual and second language education. International Journal of Bilingual Education and Bilingualism, 7(2-3), 172-188. https://doi.org/10.1080/13670050408667807 
National Ministry of Education -MEN (2016). La práctica pedagógica como escenario de aprendizaje. https://www.mineducacion.gov.co/1759/articles-357388_recurso_1.pdf

Norton, B. (2006). Identity as a socio-cultural construct in second language education. In K. Cadman \& K. O'Regan (Eds.), TESOL in Context [Special Issue], 22-33.

Olsen, B. (2008). Introducing teacher identity and this volume. Teacher Education Quarterly, 35(3), 3-6.

Pennington, M., \& Richards, J. C. (2016). Teacher identity in language teaching: Integrating personal, contextual, and professional factors. RELC Journal, 47, 5-23.

Quintero Mejía, M. (2018). Usos de las narrativas, epistemologías y metodologías: Aportes para la investigación. Editorial Universidad Distrital Francisco José de Caldas.

Richards, J. C. (2009). Second language teacher education today. RELC Journal, 39(2), 158-177.

Richards, J., \& Crookes, G. (1988). The Practicum in TESOL. TESOL Quarterly, 22(1), 9-27. https://doi.org/10.2307/3587059

Richards, J. C., \& Schmidt, R. (2002). Longman dictionary of language teaching and applied linguistics. Pearson Education.

Rodgers, C., \& Scott, K. (2008). The development of the personal self and professional identity in learning to teach. Routledge.

Samacá Bohórquez, Y. (2012). On rethinking our classrooms: A Critical Pedagogy view. HOW, 19(1), 194-208.

Ubaque-Casallas, D. F., \& Aguirre-Garzón, E. (2020). Re-signifying teacher epistemologies through lesson planning: A study on language student teachers. Profile: Issues in Teachers' Professional Development, 22(2), 131-144. https://doi.org/10.15446/profile.v22n2.80687

Van Manen, M. (1977). Linking ways of knowing with ways of being practical. Curriculum Inquiry, 6, 205-228. 


\section{Appendix. MATRIX 1. Pre-service English language teachers' reflective journals}

\begin{tabular}{|c|c|c|c|c|}
\hline Date / Place & Experiences & Events & $\begin{array}{l}\text { Feelings } \\
\text { And } \\
\text { Emotions }\end{array}$ & Who \\
\hline \multirow{7}{*}{$\begin{array}{l}\text { FIRST } \\
\text { PRACTICUM } \\
\text { CLASS } \\
\text { (Feb 27th, } \\
\text { 2018)/ } \\
\text { MENORAH } \\
\text { SCHOOL }\end{array}$} & $\begin{array}{l}\text { Her first } \\
\text { observation }\end{array}$ & $\begin{array}{l}\text { "In the first observation I was } \\
\text { nervous, I was afraid because it was } \\
\text { my first time in the classroom." }\end{array}$ & $\begin{array}{l}\text { Nervous } \\
\text { and afraid }\end{array}$ & \\
\hline & $\begin{array}{l}\text { Her first contact } \\
\text { with the students }\end{array}$ & $\begin{array}{l}\text { "I was afraid that the students made } \\
\text { a lot of noise, but when I arrived } \\
\text { to the classroom, they saw me so } \\
\text { strange because in this school, they } \\
\text { never have been a practicum teacher" }\end{array}$ & Afraid & $\begin{array}{l}\text { The } \\
\text { students' } \\
\text { group }\end{array}$ \\
\hline & \multirow{2}{*}{$\begin{array}{l}\text { Her opinion } \\
\text { about teacher's } \\
\text { activity }\end{array}$} & $\begin{array}{l}\text { "This activity was so crazy } \\
\text { because the picture was ugly, it was a } \\
\text { picture that the students didn't know" }\end{array}$ & & \multirow{2}{*}{$\begin{array}{l}\text { Teacher } \\
\text { and } \\
\text { students }\end{array}$} \\
\hline & & $\begin{array}{l}\text { "I think that the activity had } \\
\text { to be with a picture that they } \\
\text { know like a Peppa Pig, Mickey } \\
\text { Mouse, something like that" }\end{array}$ & & \\
\hline & Her conclusion & $\begin{array}{l}\text { "In conclusion, I felt good because } \\
\text { I love the children, I wanted this, } \\
\text { I want to teach to children. }\end{array}$ & Good & \\
\hline & Her preferences & $\begin{array}{l}\text { "I prefer preschool, } \\
\text { kindregarden but it's ok." }\end{array}$ & & \\
\hline & $\begin{array}{l}\text { Her opinion } \\
\text { about students }\end{array}$ & "They are so cute." & & \\
\hline
\end{tabular}


Pre-Service English Language Teachers' Levels of Reflectivity during the Process of Identity Construction in Pedagogical Practicum: A Snowball?

\begin{tabular}{|c|c|c|c|c|}
\hline Date / Place & Experiences & Events & $\begin{array}{l}\text { Feelings } \\
\text { And } \\
\text { Emotions }\end{array}$ & Who \\
\hline \multirow{6}{*}{$\begin{array}{l}\text { SECOND } \\
\text { CLASS } \\
\text { (March } \\
\text { 03rd, 2018)/ } \\
\text { MENORAH } \\
\text { SCHOOL }\end{array}$} & $\begin{array}{l}\text { Her greeting } \\
\text { the students }\end{array}$ & $\begin{array}{l}\text { "When I arrived to the classroom, } \\
\text { they say hello, but in Spanish, } \\
\text { and I said hello in English, they } \\
\text { understood that "Hello" is "Hola"." }\end{array}$ & & Students \\
\hline & $\begin{array}{l}\text { Her goal for } \\
\text { the next class }\end{array}$ & $\begin{array}{l}\text { "I hope that in the next class } \\
\text { they greet in English" }\end{array}$ & & \\
\hline & $\begin{array}{l}\text { Her interaction } \\
\text { with the teacher }\end{array}$ & $\begin{array}{l}\text { "The teacher said to me in the last } \\
\text { class that in this class the topic } \\
\text { was "fruits and vegetables" }\end{array}$ & & The teacher \\
\hline & $\begin{array}{l}\text { Her perspective } \\
\text { about the teacher's } \\
\text { use of language }\end{array}$ & $\begin{array}{l}\text { "I could see that the teacher } \\
\text { sometimes speaks in Spanish for } \\
\text { making to them understand better, } \\
\text { but the rest of the class he speaks } \\
\text { in English but with short phrases. }\end{array}$ & & The teacher \\
\hline & $\begin{array}{l}\text { The method that } \\
\text { the teachers apply } \\
\text { with their students } \\
\text { for silence. }\end{array}$ & $\begin{array}{l}\text { "He has a song in order to they } \\
\text { make silence this song consists } \\
\text { to say the parts of the body." }\end{array}$ & & \\
\hline & Her conclusion & $\begin{array}{l}\text { "In conclusion, they learnt all } \\
\text { the colors and some fruits and } \\
\text { vegetables also, it was a good class." }\end{array}$ & & \\
\hline
\end{tabular}




\section{MATRIX 2. Semi-structured interview}

\begin{tabular}{|c|c|c|c|}
\hline 6:09 & $\begin{array}{l}\text { The time limits that } \\
\text { she had in her sessions }\end{array}$ & $\begin{array}{l}\text { "El tiempo también es muy complicado, porque } \\
\text { como todos los pelados no se toman el mismo } \\
\text { tiempo para hacer las cosas, porque algunos les } \\
\text { da por mirar a la ventana, hablar con la novia, lo } \\
\text { que sea, entonces también se prolongan las cosas, } \\
\text { y las actividades se vuelven más hartas..." }\end{array}$ & \\
\hline $6: 23$ & $\begin{array}{l}\text { Her position with } \\
\text { the students }\end{array}$ & $\begin{array}{l}\text { "Y le toca decirle a uno quiubo, hágale, a pesar } \\
\text { de que son estudiantes grandes, entonces } \\
\text { ese ha sido uno de los compliques" }\end{array}$ & \\
\hline $6: 30$ & Movie time & $\begin{array}{l}\text { "Vimos una película, los puse a ver una película y } \\
\text { como son A1, pues no puedo ponerles así como } \\
\text { Terminator, ni nada de esas cosas, entonces tocó } \\
\text { ponerles la de la niña ésta de los ojos de botón..." }\end{array}$ & \\
\hline $6: 42$ & Students' reaction & $\begin{array}{l}\text { "Y claro todos súper, aaayyyy no profe pero ya vi esa } \\
\text { película, esa película la veo con mi sobrina, no sé qué" }\end{array}$ & \\
\hline $6: 49$ & $\begin{array}{l}\text { Her argument } \\
\text { about the movie }\end{array}$ & $\begin{array}{l}\text { "Pues es acorde al nivel, yo no les puedo poner } \\
\text { nada así con unos diálogos ni los hijuemadres, } \\
\text { porque no les puedo poner subtítulos" }\end{array}$ & \\
\hline $7: 01$ & Students' attitude & $\begin{array}{l}\text { "Los puse a ver la película y no, súper distraídos, } \\
\text { yo les había dicho que trajeran comida, empezaron } \\
\text { a tirar el maíz pira, fue un desastre horrible..." }\end{array}$ & \\
\hline $7: 09$ & & "Paré la película y les dije recojieran" & \\
\hline $7: 15$ & \multirow{3}{*}{$\begin{array}{l}\text { Her attitude about } \\
\text { the chaos }\end{array}$} & $\begin{array}{l}\text { "Les dije bueno aquí tampoco se } \\
\text { van a poner en ese plan " }\end{array}$ & Angry \\
\hline $7: 25$ & & "A mí me pareció muy paila" & \\
\hline $7: 28$ & & $\begin{array}{l}\text { "Y pelados que ya van por los } 25 \text {, porqué se } \\
\text { están lanzando maíz, que verguenza" }\end{array}$ & \\
\hline $7: 35$ & \multirow{2}{*}{$\begin{array}{l}\text { Her memories about } \\
\text { her last students and } \\
\text { their disposition }\end{array}$} & $\begin{array}{l}\text { "Eso lo espero de un niño, ni siquiera los niños } \\
\text { con los que trabajé en la otra práctica" }\end{array}$ & \\
\hline $7: 42$ & & $\begin{array}{l}\text { "Ellas eran súper organizadas, ella ni comían en el } \\
\text { salón, para o ensuciar los puestos de las otras chicas... }\end{array}$ & \\
\hline $8: 45$ & $\begin{array}{l}\text { Her greeting } \\
\text { the students }\end{array}$ & "Esa combinación es increíble, el spanglish de ellos" & \\
\hline $8: 46$ & $\begin{array}{l}\text { Initiative to use English } \\
\text { in different situations. }\end{array}$ & $\begin{array}{l}\text { "Hola teacher, necesito algo y uno mmmm } \\
\text { elaboralo, no no te entiendo, imaginemos } \\
\text { que yo no te estoy entendiendo lo que estás } \\
\text { diciendo, pero te entiendo perfectamente" }\end{array}$ & \\
\hline
\end{tabular}


Pre-Service English Language Teachers' Levels of Reflectivity during the Process of Identity Construction in Pedagogical Practicum: A Snowball?

\begin{tabular}{|l|l|l|l|}
\hline $9: 07$ & Students' interaction & "Lo que me gusta es que ellos preguntan mucho" & \\
\hline 9:11 & \multirow{2}{*}{ The special student } & $\begin{array}{l}\text { "Hay un muchacho, que no sé, él tiene } \\
\text { ayuditas de alguien, porque en aula virtual } \\
\text { el tipo UFFF, vuela con esa aula" }\end{array}$ & \\
\cline { 3 - 4 } $9: 13$ & & "Pero yo lo pongo en el salón y él no entiende cosas" & \\
\hline $9: 39$ & The extra help & "Sí, eso es lo maluco, yo creo que les ayudan" & \\
\hline
\end{tabular}

